\title{
Infestation of rural houses by Triatoma infestans in the region of Los Llanos (La Rioja, Argentina)
}

\author{
X Porcasi, H Hrellac*, S Catalá, M Moreno, L Abrahan, L Hernandez, DE Gorla/ ${ }^{+}$
}

Centro Regional de Investigaciones Científicas y Transferencia Tecnológica. CEP 5301 Anillaco, La Rioja, Argentina *Dirección Provincial de Chagas, La Rioja, Argentina

\begin{abstract}
Vectorial transmission of Chagas disease has been strongly reduced in most parts of the Southern Cone countries of South America, except in the Gran Chaco region of Argentina, Bolivia, and Paraguay. Given periodical interruptions of the vector control programmes in the endemic region of the Gran Chaco of Argentina, the vectorial transmission of the disease has been increasing during the last years. From the beginning of 2004, the provincial Ministry of Health of La Rioja, Argentina, started a vector control programme to cover the rural houses of the Los Llanos area in the southwestern area of the Gran Chaco region. This article reports the result of a standardized entomological survey and insecticide application against Chagas disease vectors in the intra and peridomestic structures of the rural houses of Los Llanos. A total of 4062 houses were inspected, of which $46.8 \%$ were found to be infested by Triatoma infestans. Infestation by vector species other than $\mathrm{T}$. infestans was less than $0.5 \%$ (T. eratyrusiformis and T. platensis). Intradomestic infestation was found in $27.2 \%$, whereas peridomestic infestation was found in $39.3 \%$ of the houses. The lowest figure of intradomestic infestation was $6.6 \%$ (Department F Varela), and the highest value of intradomestic infestation was 45.1\% (Department Independencia). In spite of the demonstrated success of vector control elsewhere, this study shows that the vector populations are susceptible to pyrethroid insecticides in the southern area of the Gran Chaco of Argentina, that there still are regions where rural houses show heavy infestation by $\mathrm{T}$. infestans associated with big peridomestic structures and that the vectorial transmission of the Chagas disease will continue, unless a sustained and well organized vector control effort is installed in the region.
\end{abstract}

Key words: Chagas disease - Triatoma infestans - vectorial control - Triatominae - Argentina

The important overall success of the Southern Cone Initiative for the elimination of domestic infestation by Triatoma infestans, that interrupted the vectorial transmission of Chagas disease by this species in Chile, Uruguay, parts of Argentina, Bolivia, Paraguay, and in the whole of Brazil (Schofield et al. 2006), contrasts with the recent increase of Chagas disease case numbers in the Gran Chaco region of Argentina (Gürtler et al. 2005). This increase could be associated with two main causes.

On one side, the change of structure of the control programmes, from vertical hierarchical structures to horizontal decentralized ones, was followed by a progressive weakening of vector control activities. From 1998, the Argentine economy began to decline, reaching a nadir by the end of 2001. This process was accompanied by a marked reduction of the health budget that progressively halted the vector control activities at the national and provincial levels. This trend has little changed within most of the historically endemic region,

This work is part of the 5-year Programme for the Control of Chagas Disease of the La Rioja Ministry of Health (Argentina), started in 2004

Financial support: Comisión Nacional de Actividades Espaciales of Argentina, Consejo Nacional de Investigaciones Científicas y Técnicas of Argentina, Ministerio Salud La Rioja

${ }^{+}$Corresponding author:dgorla@crilar-conicet.com.ar

Received 4 August 2006

Accepted 21 November 2006 so that vector control activities, search for infected people, and parasitological treatment, has become almost non-existent due to the lack of specific budgets for control and vigilance activities at the provincial levels, as well as lack of personnel and vehicles for field work.

A newer effect, at least for its relative magnitude, is the identification of problems for the elimination of peridomestic populations of $T$. infestans in the Gran Chaco region of Argentina with existing vector control methods. These problems had long been identified by the studies of Cécere et al. (1997), and there is now a remarkable contrasting situation between the Gran Chaco and elsewhere. Almost all regions outside the Gran Chaco certified the interruption of the vectorial transmission due to T. infestans. Besides Uruguay, Chile, and Brazil, five provinces of Argentina outside of the Gran Chaco (Jujuy, Neuquén, Río Negro, La Pampa, and Entre Ríos), as well as the Department of Amambay (Paraguay) have certified the interruption of Chagas disease transmission due to T. infestans (INCOSUR 2003). However, within the Gran Chaco the situation is very different, with rural areas showing high house infestation rates and increasing numbers of new cases.

The Gran Chaco is a natural region of about $1.000,000$ $\mathrm{km}^{2}$, extending over parts of Bolivia, Paraguay, Brazil, and Argentina. Human population density is low, usually averaging fewer than five people per $\mathrm{km}^{2}$. The vegetation of the Chaco is a mosaic of forest, woodlands, savannas, and grasslands. Once covered in several areas by extensive forests and grasslands (by early 1900s), wood overexploitation and overgrazing left many impoverished 
areas covered by scrub. In many areas, one of the options for the small rural producers is goat production, frequently associated with the presence of goat corrals that usually harbour hundreds or even thousands of $T$. infestans (Bucher \& Schofield 1981). The Gran Chaco of Argentina includes the poorest provincial departments of Argentina, 31.6\% of the homes (over 562,094) have unsatisfied basic needs as compared with $13.3 \%$ of the homes (over 9.513,720) with unsatisfied basic needs outside the Gran Chaco (data from the 2001 national census, www.indec.gov.ar).

When the Chagas vector control activities began as a national programme by mid 1960 s, rural houses of La Rioja showed heavy infestation by $T$. infestans $(>50 \%)$, that dropped to less than $20 \%$ by the mid 1990 s when the Southern Cone Initiative started. Seroprevalence of 18 year men summoned for military service between 1981 and 1993 showed no change during the period (seroprevalence decreased elsewhere in Argentina), averaging 9.4\% (Segura et al. 2000). During the 1990s, the national programme for the control of Chagas disease decentralized the activities of vector control, transferring the responsibility to the provinces. For the case of La Rioja, this decentralization resulted in a virtual stagnation of vector control activities for about 10 years, with individual houses irregularly sprayed by non-professional personnel after house owners denounced infestation by T. infestans (Segura 2002).

During the 1990 decade, important sociological changes occurred at the provincial level, with the populations of the western valleys improving their living standard, whereas the populations of the eastern plains of Los Llanos continued an impoverishment cycle. During this period, vector control activities in La Rioja where progressively dismantled due to the lack of resources and a policy to sustain a Chagas Programme. The situation reached a critical status by the beginning of 2000 , with the big national socio-economic crisis. Unfortunately, the disorganisation of the programme activities at the provincial level, coupled with a very poor national capacity to supervise and control those activities, lead to a virtual inexistence of historical data to disaggregate any analysis below the provincial scale. It was known that the vectorial transmission of Chagas disease within the western valleys of La Rioja was very low, either because the cooler climate or the better living conditions. It was also suspected that the vectorial transmission within the Los Llanos region was never interrupted and maintained a high prevalence level. The last situation was later confirmed by a field serological survey in one of the eight provincial departments of Los Llanos, where $10 \%$ of the children younger than 15 years were found infected (Programa Chagas La Rioja, unpublished data).

The region of Los Llanos in the province of La Rioja is located to the south of the Gran Chaco and constitutes one of the most arid and poorest regions of Argentina. Within this area, $72 \%$ of the rural population follow a system of small farm producers, occupying 38\% of the total surface of Los Llanos (4 million hectares) (Gorla et al. 2005). These small farms make an integral exploitation of all the available resources in a subsistence economy system for the family group.

Within the Los Llanos of La Rioja, goat breeding is one of the most important activities for the small farmers. Goat corrals are one of the most important refuges for the peridomestic populations of $T$. infestans and one of the ecotopes where the insecticide application against T. infestans shows the lowest efficiency, leaving residual populations that recover after 1 or 2 years (Cécere et al. 1997, Gürtler et al. 2004, Porcasi et al. 2006). By 2002 the health ministry of La Rioja reactivated the vector control activities, and by 2004, the Government of La Rioja approved a 5 year programme for the control of Chagas disease, targeting all rural houses (intra and peridomestic structures) of the eight provincial departments within the region of Los Llanos.

The objective of this article is to inform about the results of a survey on entomological indicators for Chagas disease in the rural communities of the Los Llanos region (La Rioja, Argentina).

\section{METHODS}

The area covered by the Programa Chagas La Rioja (PChLR) between 2004 and 2005 included 8 departments (AV Peñaloza, Belgrano, Quiroga, Varela, Independencia, Ocampo, RV Peñaloza, and San Martín), with 4062 rural and periurban houses. Field surveys were carried out during the warm months, between September and April each year.

A house by house survey was carried out by four technicians of the PChLR per house. Two persons inspected intradomestic structures (ID) whereas the other two inspected the peridomestic structures (PD). The two teams searched independently during at least $15 \mathrm{~min}$ in each area with the aid of aqueous tetramethrin $(0.2 \%)$ as an irritant dislodging agent. If a live T. infestans appeared, the search was terminated in that particular ecotope. The house was consequently recorded as infested either in the ID, in the PD or in both ecotopes (IDPD), depending on where the insects were found. After the house inspection, demographic data of the family was recorded on a standard form, the house was identified by an individual number painted on a house wall and house location (latitude and longitude coordinates) was recorded using a Garmin Legend GPS. After all data were recorded, all the inner surfaces of the house and external sides of the walls, as well as all the peridomestic structures (corrals of domestic animals, storage places, etc.) were sprayed with deltamethrin 2.5\% (Bayer), alfacypermethrin 6\% (Basf) or betacypermethrin 5\% (Chemotecnica) using 5-litre manual sprayers with Schmitt 8002 fan nozzles. In addition to the pyrethroid spray, sleeping rooms of very isolated houses were treated with one fumigant canister per room (Musal, Chemotecnica) if the room structures were closed enough to ensure a high efficiency of the insecticidal smoke.

Given published reports about the detection of pyrethroid resistance in the localities of San Antonio and Cuatro Esquinas in the region of Los Llanos (Orihuela $\&$ Picollo 2005), the PChLR and a similar programme developed in the neighbour province of Catamarca, car- 
ried out a monitoring programme for susceptibility to pyrethroid insecticides in collaboration with the entomology laboratory at the CRILAR. Specimens of 13 localities ( 8 from La Rioja and 5 from Catamarca) were tested for susceptibility to deltamethrin, according to the protocol described by OMS (1994). Briefly, groups of 10 first instar nymphs obtained from field collected females and within 5-7 days after hatching were used in three replicates by locality. Each specimen in the "treatment" group was given a topical application of $0.2 \mu \mathrm{l}$ of an acetone solution $(0.01 \mathrm{mg} / \mathrm{ml})$ of deltamethrin $(98 \%$, Bayer) and left under a constant temperature of $27^{\circ} \mathrm{C}$. An equivalent set of replicates of control specimens from a susceptible population (provided by the insect rearing facility of the Coordinación Nacional de Control de Vectores, Punilla - Córdoba) received only acetone. Mortality of treated and control specimens was recorded 72 hours after the topical application.

\section{RESULTS}

A total of 4062 rural houses was inspected in the intra and peridomestic structures. In only 20 of them (less than $0.5 \%$ ) other species different from $T$. infestans were found in peridomestic structures, namely $T$. platensis and T. eratyrusiformis. Among the 4062 houses, 46.8\% were infested in the intra and/or peridomestic structures or both, $27.1 \%$ had intradomestic infestation and 39.3\% had peridomestic infestation (Table I).

The provincial department with the lowest infestation was F Varela, with $20.6 \%$ of infested houses, of which $6.6 \%$ was intradomestic and $17.6 \%$ was peridomestic. In contrast, departments AV Peñaloza, San Martin, RV Peñaloza, and Independencia showed more than $50 \%$ of the houses with infestation by $T$. infestans. RV Peñaloza and Independencia had more than $40 \%$ of the houses with intradomestic infestation (Table I). Exclusive intradomestic infestation was found infrequently (7.5\% of the houses); exclusive peridomestic infestation or mixed infestation (IDPD) were more frequent and with similar numeric importance (19.7 and 19.6\% of the houses, respectively) (Fig. 1).
Considering the infested houses, the Department $\mathrm{F}$ Varela showed most of the infestation exclusively in the peridomestic structures. The Department RV Peñaloza showed the highest exclusive intradomestic infestation and the lowest exclusive peridomestic infestation (Table II). Although an inverse relationship between intra and peridomestic infestation could be expected, a correlation analysis between exclusive ID and PD infestation showed no significance $(r=0.57, p>0.05, n=9)$.

Using the georeferenced database of the PChLR the total number of houses and number of infested houses in a grid of $4.5 \mathrm{~km}$ cells were calculated and used to build two layers over imposed in Fig. 2, that shows the location of the inspected and georeferenced rural houses during 2004 and 2005. Localities of the Department Ocampo will be georeferenced during 2006.

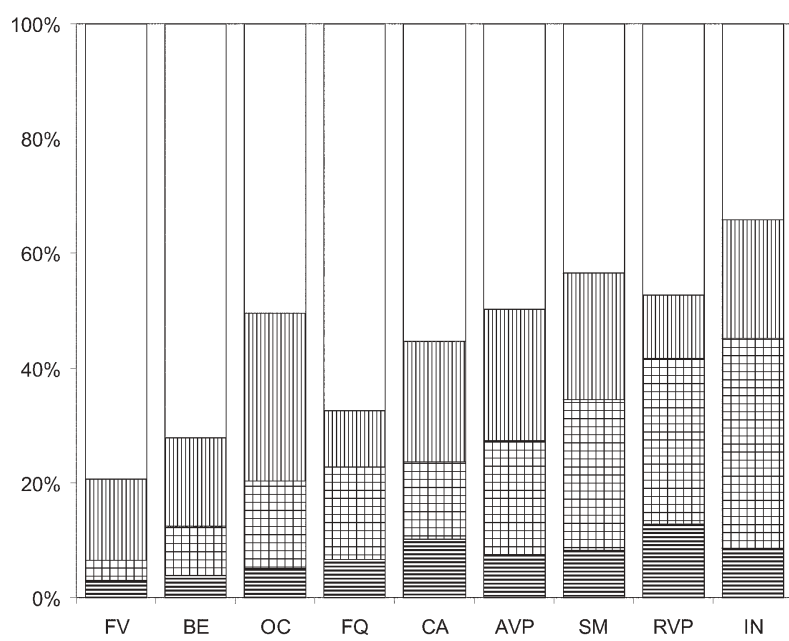

Fig. 1: distribution of rural house infestation by Triatoma infestans in the region of Los Llanos (La Rioja), discriminated by infested ecotope. ID: intradomestic infestation (horizontal lines); PD: peridomestic infestation (vertical lines); IDPD: intra and/or peridomestic infestation (quadrille); negative houses: no lines; FV: F Varela; BE: Belgrano; OC: Ocampo; FQ: F Quiroga; AVP: AV Peñaloza; SM: San Martín; RVP: RV Peñaloza; IN: Independencia.

TABLE I

Total number of rural houses inspected and treated with insecticide in each department

\begin{tabular}{|c|c|c|c|c|c|c|c|}
\hline \multirow{2}{*}{$\begin{array}{l}\text { Provincial } \\
\text { department }\end{array}$} & \multirow{2}{*}{$\begin{array}{c}\text { Total } \\
\text { number } \\
\text { of houses }\end{array}$} & \multicolumn{3}{|c|}{ Number of infested houses } & \multicolumn{3}{|c|}{ House infestation $(\%)$} \\
\hline & & ID & $\mathrm{PD}$ & IDPD & Total & ID & PD \\
\hline F Varela & 335 & 10 & 47 & 12 & 20.6 & 6.6 & 17.6 \\
\hline Belgrano & 392 & 15 & 60 & 34 & 27.8 & 12.5 & 24.0 \\
\hline Ocampo & 899 & 46 & 264 & 136 & 49.6 & 20.2 & 44.5 \\
\hline F Quiroga & 528 & 35 & 52 & 85 & 32.6 & 22.7 & 25.9 \\
\hline Capital & 228 & 23 & 48 & 31 & 44.7 & 23.7 & 34.6 \\
\hline AV Peñaloza & 330 & 25 & 76 & 65 & 50.3 & 27.3 & 42.7 \\
\hline San Martin & 546 & 45 & 121 & 143 & 56.6 & 34.4 & 48.4 \\
\hline RV Peñaloza & 557 & 71 & 62 & 161 & 52.8 & 41.7 & 40.0 \\
\hline Independencia & 164 & 14 & 34 & 60 & 65.8 & 45.1 & 57.3 \\
\hline Total & 3644 & 274 & 717 & 715 & 46.8 & 27.1 & 39.3 \\
\hline
\end{tabular}

ID: number of houses with intradomestic infestation; PD: number of houses with peridomestic infestation; IDPD: number of houses with intra and peridomestic infestation. 


\section{TABLE II}

House infestation by Triatoma infestans, relative to the total number of infested houses in each department, figures indicate the relative weight of the infested place (ID, PD or both)

\begin{tabular}{lrcr}
\hline & \multicolumn{3}{c}{ Relative infestation (\%) } \\
\cline { 2 - 4 } Provincial department & ID & PD & IDPD \\
\hline F Varela & 14.5 & 68.1 & 17.4 \\
Belgrano & 13.8 & 55.0 & 31.2 \\
Ocampo & 10.3 & 59.2 & 30.5 \\
F Quiroga & 20.3 & 30.2 & 49.4 \\
Capital & 22.5 & 47.0 & 30.4 \\
Gral Peñaloza & 15.1 & 45.8 & 39.1 \\
San Martin & 14.6 & 39.2 & 46.3 \\
RV Peñaloza & 24.1 & 21.1 & 54.8 \\
Independencia & 12.9 & 31.5 & 55.5 \\
\hline Total & 16.1 & 42.0 & 41.9 \\
\hline
\end{tabular}

ID: number of houses with intradomestic infestation; PD: number of houses with peridomestic infestation; IDPD: number of houses with intra and peridomestic infestation.
The PChLR sprayed 3787 houses with pyrethroid insecticides, using 41271 of suspension concentrate (SC) insecticide, plus 2814 fumigant canisters. An average of 1.091 of the SC formulation per house was used, with a minimum of 0.61 per house in the Department RV Peñaloza and a maximum of 1.61 per house in the Department Belgrano. The variation in the amount of insecticide used in each house depended on the size of the peridomestic structures (Table III).

All tested T. infestans specimens that hatched from eggs laid by field collected females showed susceptible for deltamethrin. In general, treated specimens showed mortality rates over $95 \%$ whereas specimens of the control groups showed mortality that did not exceed 5\% (Table IV).

\section{DISCUSSION}

Vectorial transmission of Chagas disease has been strongly decreasing in the southern cone countries of Latin America. Chile in 1997, Uruguay in 1999 and re-

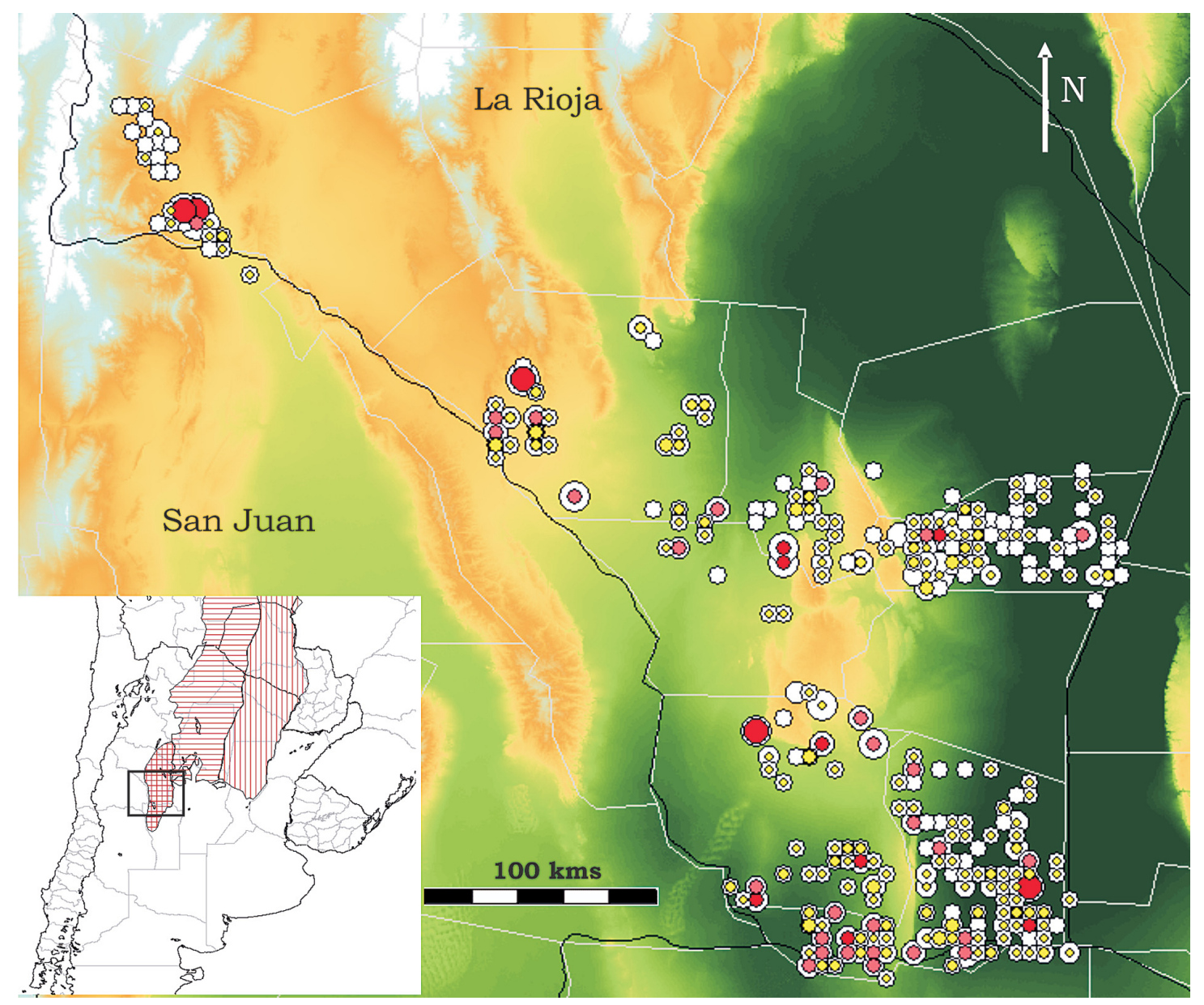

Fig 2: distribution of rural houses inspected by the Programa Chagas La Rioja and infestation by Triatoma infestans (intra and/or peridomestic structures). Map produced by the GIS-Chagas-LR system. Background colour shows terrain elevation (masl; white is over $4000 \mathrm{~m}$, deep green is around $200 \mathrm{~m}$ ). White circles: total number of houses (represented by circle size); colour circles: number of infested houses as follows, yellow: 1-5 infested houses, pink: 6-10, red small: 11-19, red big > 20 infested houses. The inset shows the location of the studied area (black box), the semiarid chaco (quadrille), arid chaco (horizontal lines) and humid chaco (vertical lines). 
TABLE III

Number of monodosis or units per type of insecticide used in each provincial department by the Programa Chagas La Rioja between 2004 and 2005

\begin{tabular}{lrrrrr}
\hline & \multirow{2}{*}{$\begin{array}{c}\text { Number of } \\
\text { treated } \\
\text { Provincial } \\
\text { department }\end{array}$} & \multicolumn{4}{c}{ Insecticide } \\
\cline { 3 - 6 } houses & $\mathrm{DE}$ & $\mathrm{FE}$ & AC & PF \\
\hline Belgrano & 392 & 6497 & 0 & 0 & 658 \\
AV Peñaloza & 330 & 1605 & 1102 & 0 & 403 \\
F Varela & 335 & 0 & 0 & 4890 & 0 \\
Capital & 228 & 2089 & 0 & 1122 & 119 \\
Quiroga & 528 & 5921 & 0 & 0 & 133 \\
RV Peñaloza & 557 & 0 & 0 & 3478 & 449 \\
Ocampo & 1417 & 14,565 & 0 & 0 & 1052 \\
San Martin & 546 & 5405 & 0 & 0 & 597 \\
\hline Total & 4333 & 36,082 & 1102 & 9490 & 3411 \\
\hline
\end{tabular}

DE: deltamethrin 2.5\%, FE: betacypermethrin 5\%, AC: alfacypermethrin $6 \%, \mathrm{PF}$ : fumigant canister (see methods for details). Figures correspond to number of monodosis $(100 \mathrm{ml})$ in the case of the pyrethroids and units in the case of the fumigant canisters.

\section{TABLE IV}

Test for susceptibility to pyrethroids, according to the WHO protocol (OMS 1994). Specimens of all localities were susceptible to deltamethrin. Each figure represents the mortality $(\%)$ in three replicates, with 10 first instar nymphs each

\begin{tabular}{llrr}
\hline & & \multicolumn{2}{c}{ Mortality } \\
\cline { 3 - 4 } Province & Locality & Control & Treatment \\
\hline La Rioja & San Antonio & 0 & 100 \\
& Balde del Carmen & 0 & 97 \\
& Los Cornejos & 0 & 97 \\
& Cruz del Eje & 4 & 100 \\
& El Caldén & 0 & 100 \\
& El Cadillo & 4 & 97 \\
& La Cañada & 4 & 100 \\
& Santa Rosa & 0 & 100 \\
& & & \\
Catamarca & Palo Blanco & 0 & 100 \\
& San Isidro (V Viejo) & 4 & 100 \\
& La Tablada & 10 & 100 \\
& El Bosquecillo & 0 & 100 \\
& San Isidro (La Paz) & 0 & 93 \\
\hline
\end{tabular}

cently Brazil (2006) have all declared the interruption of the vectorial transmission due to T. infestans in all their territories, together with one department in Paraguay and 5 provinces in Argentina (Schofield et al. 2006). This situation contrasts strongly with the vectorial transmission scenario within the region of the Gran Chaco of Argentina, where the number of acute cases has been increasingly recorded during the last years (Gürtler et al. 2005) and infestation of houses by T. infestans reaches over 50\% in some regions (Porcasi et al. 2006).

The house infestation values recorded by the Programa Chagas La Rioja during 2004-2005 over the Los Llanos region show that the rural communities of the region live under a high risk of vectorial transmission of
Chagas disease. The value of the entomological indicators of the southernmost departments of Los Llanos is similar to the situation observed during the 1960 s, previous to the initiation of the vector control activities in La Rioja. The situation is the result of the virtual deactivation of the vector control programme of the province from the second half of 1990 until 2003, and associated with poverty, low education levels, and breeding of domestic animals in large peridomestic structures that constitute good refuges for T. infestans populations. As Gürtler et al. (2004) experimentally showed in the same region, it is in these peridomestic structures that the pyrethroid insecticides show the lowest residuality. The scarcity of published reports (especially those geographically disaggregated), either at the provincial or the national levels, makes difficult a serious retrospective analysis. This trend has changed during the last two years, as a well organized Chagas disease control programme is being carried out in the province, including a detailed system of field data management. The new data management system is based on the use of GPS navigators to record the location of each rural house (identified by an individual numbering system), together with demographic, epidemiological, and domestic animal data. The information is stored in a spatial database that constitutes the core of the GIS of the Chagas Programme of La Rioja. The standardized format of the data entered into the database is updated periodically and will serve to evaluate the temporal changes of the entomological indicators.

The new programme is promising, and a special effort will be needed in the provincial departments of the Los Llanos region (La Rioja, Argentina), to solve the problem posed by the peridomestic infestation in the rural houses of the region. The peridomestic structures are known to decrease the efficiency of the insecticidal applications and a number of residual vector populations should be expected to occur in some areas (Cécere et al. 2006, Porcasi et al. 2006). If this were the case, intradomestic infestation would occur within 2 or 3 years after the insecticide application (Cécere et al. 2004) if no additional vector control activities were carried out through a sustained vigilance system. The return of the house infestation values to the starting point 40 years back, after 10 years of no vector control activities, is the outcome of a health system that was not able to sustain the effort made in the past. Other health systems of the region dealing with similar problems should take account of the experience.

\section{ACKNOWLEDGEMENTS}

To the ECLAT network. To R Stariolo and D Canale of the insect rearing facility of the Coordinación Nacional Control Vectores de Punilla (Córdoba), for the provision of susceptible specimens for the pyrethroid susceptibility tests. MM received training for susceptibility tests at the CIPEIN under the supervision of Dr MI Picollo, with our thanks for the kind support. DEG, SSC, and XP are members of the National Research Council of Argentina (Conicet). Comments of an anonymous reviewer help improve an earlier version of the manuscript. 


\section{REFERENCES}

Bucher EH, Schofield CJ 1981. Economic assault on Chagas disease. New Sci 29: 321-324.

Cécere MC, Gürtler RE, Canale D, Chuit R, Cohen J 1997. The role of the peridomiciliary area in the elimination of Triatoma infestans from rural Argentina communities. Pan Am J Public Health 1: 273-279.

Cécere MC, Vazquez-Prokopec GM, Gürtler RE, Kitron U 2004. Spatio-temporal analysis of reinfestation by Triatoma infestans (Hemiptera: Reduviidae) following insecticide spraying in a rural community in northwestern Argentina. Am $J$ Trop Med and Hyg 71: 803-810.

Cécere MC, Vázquez-Prokopec GM, Ceballos LA, Gurevitz JM, Zárate JE, Zaidenberg M, Kitron U, Gürtler RE 2006. Comparative trial of effectiveness of pyrethroid insecticides against peridomestic populations of Triatoma infestans in northwestern Argentina. J Med Entomol 43: 902-909.

Gorla DE, Catalá SS, Porcasi X, Moreno M, Abrahan L, Carrizo H 2005. Manejo ambiental de estructuras peridomésticas para eliminar la infestación por Triatoma infestans en Los L1anos de La Rioja. Technical Report Project No 1002, Programa Vigía. Ministry of Health Argentina, 7 pp.

Gürtler RE, Canale DM, Spillman C, Stariolo R, Salomón OD, Blanco S, Segura EL 2004. Effectiveness of residual spraying of peridomestic ecotopes with deltamethrin and permethrin on Triatoma infestans in rural western Argentina: a districtwide randomized trial. Bull WHO 82: 196-205.

Gürtler RE, Cécere MC, Lauricella MA, Petersen RM, Chuit R, Segura EL, Cohen JE 2005. Incidence of Trypanosoma cruzi infection among children following domestic reinfestation after insecticide spraying in rural northwestern Argentina. Am J
Trop Med and Hyg 73: 95-103.

INCOSUR 2003. XII Reunión de la Comisión Intergubernamental para la Eliminación de Triatoma infestans y la Interrupción de la Tripanosomiasis Americana por Transfusión. OPS/DPC/ $\mathrm{CD} / 270 / 03$

OMS 1994. Protocolo de evaluación de efecto de insecticida sobre triatominos. Acta Toxicol Argentina 2: 29-32.

Orihuela S, Picollo MI 2005. Evaluación de actividad de enzimas esterasas específicas a insecticidas piretroides en poblaciones resistentes de Triatoma infestans (Hemiptera: Reduviidae) provenientes de las provincias de Salta y de La Rioja. Congreso Argentino de Entomología, San Miguel de Tucumán (12-15 de Septiembre).

Porcasi X, Catalá SS, Hrellac H, Scavuzzo MC, Gorla DE 2006. Infestation of rural houses by Triatoma infestans (Hemipera: Reduviidae) in the southern area of the Gran Chaco in Argentina. J Med Entomol 43: 1060-1067.

Schofield CJ, Jannin J, Salvatella R 2006. The future of Chagas disease control. Trends Parasitol (in press).

Segura EL 2002 El control de la enfermedad de Chagas en la República Argentina. In AC Silveira, El Control de la Enfermedad de Chagas en los Países del Cono Sur de América. Historia de una iniciativa internacional 1991/ 2001, Faculdade de Medicina do Triangulo Mineiro, Uberaba, p. 45-108.

Segura EL, Cura EN, Sosa Estani SA, Andrade J, Lansetti JC, de Rissio AM, Campanini A, Blanco SB, Gürtler RE, Alvarez M 2000. Long-term effects of a nation-wide control program on the seropositivity for Trypanosoma cruzi infection in young men from Argentina. Am J Trop Med Hyg 62: 353362. 